\title{
Rheological Behavior of Bentonite-Water System from a Small Distortion to Rupture
}

by

\author{
Kenji OKada*1, Tomomi TaKagI*2, and Yoichi NAGASE*1 \\ *1 Dept. of Chem. Eng., Hiroshima Univ., Higashi Hiroshima-shi 724 \\ *2 Daicel Chemical Industries, LTD., Himeji-shi, Hyogo 671
}

\begin{abstract}
Torsional shear tests were performed with a cone and plate type rheometer on a 7.5 vol\% Bentonite slurry. To acquire real distortion and stress breakdown phenomena of the slurry, photographic visualizations were carried out simultaneously with the shear tests using lines marked on the sample surface as markers. The sample were elastic within small strain of less than 0.1 , irrespective of the strain history. Stress increased with increasing strain beyond the elastic limit and exhibited an overshoot. The extent of the stress overshoot depended greatly on the rate of strain. The phenomenon corresponded with the fact that the width of sliding layer in the sample increased with increasing strain rate. Therefore, under a limiting strain rate, the breakdown of the sample took place only in a limited region but not in the whole specimen. Above a certain critical strain-rate, the sample exhibited thixotropic behavior. The sliding layer became narrower with time and finally became very thin at steady state. Stress-strain rate curve at steady state showed a different characterstics below and above this limiting strain rate. Stress hysteresis was also observed in the region slightly above the yield point.
\end{abstract}

\section{ベントナイトスラリーの低ひずみから破断に 至る間のレオロジー的性質}

岡 田賢 治 ${ }^{* 1} \cdot$ 高 木 基 實 ${ }^{* 2}$ 長 瀬 洋 一 ${ }^{* 1}$

（原稿受理：1981年12月18日）

\section{1. 緒言}

固体粒子の分散系に対するレオロジー研究は，その流動特性に 関するあのが多い。しかし，分散系に特有の性質といわれる塑性 は本来, 静的特性に関するあのであり, またチキントロピー, ダ イラタンシー, レオペクシーなども塑性破壊後の低いずり速度に おいてより顕著に現われるようである，そのために最近では，塑

*1 広島大学工学部化学工学教室 $\mathbf{T} 724$ 東広島市西条町大字下見

*2 ダイセル化学工業(株) $\mathbf{T} 671$ 兵車県姬路市網干区新左家
性や低いせん断速度域における非定常1),2),3) - 定常4),5)特性が注 目されている.ところで金属材料にもみられるように，例えば塑 性は破壊に際して材料内応力分布の急激な变化を伴うので, これ の認識にはまず現象の実際的知識を積み上げる必要があると考え られる。

そてで, 本研究は分散系の代表例としてょく用いられるベント ナイトスラリーについて, 静置状態から流動飞至る間を対象とし, 通常のレオロジー測定と並行して流体力学でよく用いられる可視 化の方法によって現象の実状を得ようと試みた。 


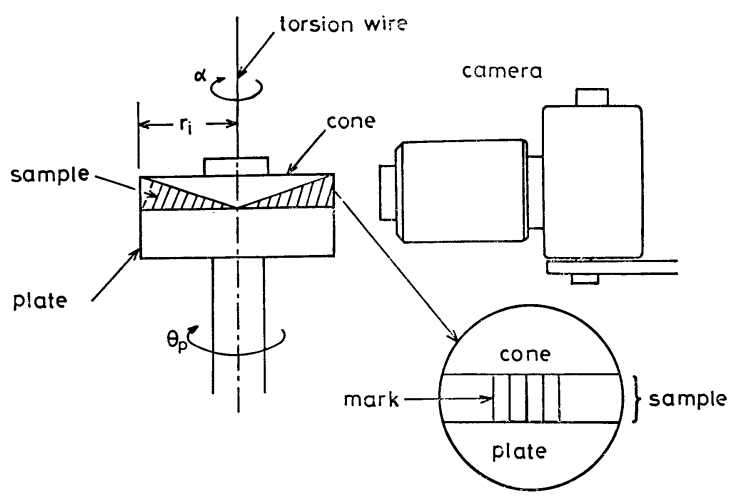

Fig. 1 Schematic diagram of measuring device.

\section{2. 実験}

\section{$2 \cdot 1$ 測定装置および測定方法}

スリラーの静置から流動に至る間の実際を直接に可視化する目 的であるので, てれの容易な装置として円錐-平板型レオメータ を選び，自作した。 Fig. 1 亿測定部を示す。平板を回転させ，円 錐に直結したトーションワイヤによってトルクを測定する。内錐 一平板直径 $2 r_{i}$ は $5 \mathrm{~cm}$, 間隙角度 $\beta_{0}$ は $3.34^{\circ}$ とし, 比較のため に $\beta_{0}=1.77^{\circ}$ のあのあ一部用いた. 試料を円錐-平板間に仕込み 所定時間放置した後, Fig. 1 亿付記したように試料側表面に油性 顔料で細い縦のマーク線を引き, 静置状態から平板に低速度の回 転を与える. 测定中のマーク線の変形状況をひずみ一応力の测定 と並行して直接写真撮映した. 平板および円錐のねじれ角 $\theta_{p}, \alpha$ はそれぞれに固定してある円板磁気スケール（分解能 $0.03^{\circ}$ ）に より検出される. 平板の回転角制御は関数発生機, プリントモー タおよび多段減速機によって行い，回転角の印加波形は Fig. 2 に示すような 3 つのモードを使用した．Ｉは所定の回転角まで連 続的に増加させる，IIはステップ状に，IIIは正弦波状に増減する 方法*1である。いずれす平板の回転角加速度 $d^{2} \theta_{p} / d t^{2}=5.16 \times$ $10^{-4} \sim 3.03 \times 10^{1} \mathrm{deg} / \mathrm{s}^{2}$ まで可変出来る．なお，モードある 程度ねじりを与えてから回転を停止している間に（本実験では停 止時間を 2 30分とした）円錐側に応力変化が起こるかどうかを みること，モード亚は低ひずみにおける履歴の性質を検討するこ とを主目的としている. また, 測定中における試料の乾燥を防ぐ ため測定部を透明の恒温恒湿槽内に怙き, 測定温度 $20^{\circ} \mathrm{C}$, 湿度 85 〜 90\%で測定した。

測定されるひずみ $\gamma$ と応力 $\tau$ は，近似的に次式で与えられる

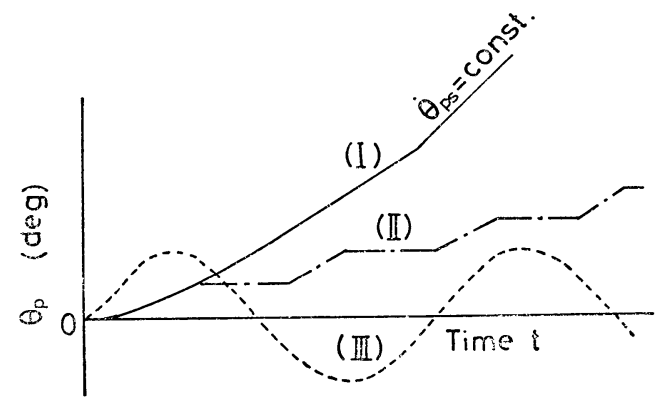

Fig. 2 Plate rotation, $\theta_{p}$, mode for shear test.

*1 ギヤーの遊びがあるために正確な正弦波形とはならない。
（次報6)参照）.

$$
\begin{aligned}
\gamma & =\frac{r_{i}\left(\theta_{p}-\alpha\right)}{r_{i} \tan \beta_{0}} \div \frac{\left(\theta_{p}-\alpha\right)}{\beta_{0}} \\
\tau & =\frac{3 M}{2 \pi r_{i}{ }^{3}}
\end{aligned}
$$

ここで，Mはねじりモーメントである。

装置の詳細は既報7記している。

\section{$2 \cdot 2$ 試 料}

武料は 6 力月間水中で熟成した 7.5 vol\% ワイオミングベント

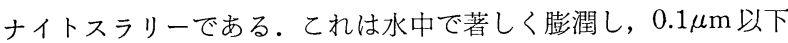
加ら $1 \mu \mathrm{m}$ 程度までの薄片状の二次微粒子となって分散している ようで, 電子顕微鏡観察したところ薄片であるためか粒子として は識別困難であった。外見はゲル状態で8), 常温で放置しておく とビーカを傾けても流れない程度に固化する。また，放置してお くと時間之共に固化が進行することがわかったので, 本実験はす べてよく混ぜかえした試料を仕込んだ後10時間放置してから行っ た。また，本試料は水中では $\mathrm{pH}=8.57$ であり，酸性になるにつれ て膨潤性が低下した。

\section{3. 結果および考察}

\section{$3 \cdot 1$ 弾性的性質}

ひずみが小さい範囲では，いずれのねじりひずみモードにおい ても弾性的な挙動を示した．モードIIの場合の一例を Fig. 3 亿 示す. (a) 図上の点 1 以下が弾性的挙動の範囲で, ての範囲では 平板の回転を停止している間に試料内で応力変化は起こらなかっ た*1)．(b) 図は $\tau$ 対 $\gamma$ 亿換算した結果である．Fig. 4(a) にも例 示した多数の測定結果より, 弾性域はスラリーの放置時間に関せ ずひずみが約 0.1 以下の範囲であった。10時間放置のときの平均

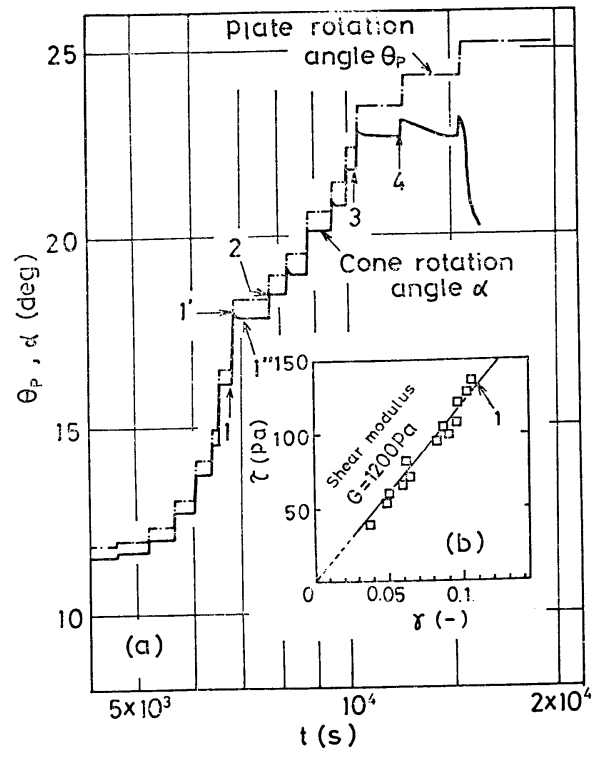

Fig. 3 Response curve of cone, $\alpha$, to stepwise distortion of plate, $\theta_{p}$, (a) and elastic behavior (b). 7.5 vol\% Bentonite solution for all of following figures.

*1 化学工業化おける諎操作は分ないし時間オーダの操作が多く, こ 机々同程度の時間スケールに沏ける変化を本研究の当面の課題に している. 


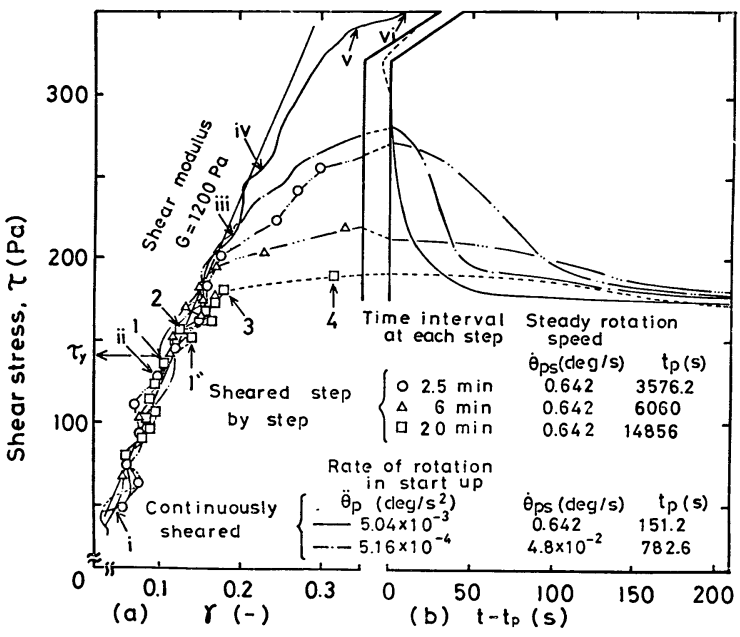

Fig. 4 Stress response, $\tau$, from elastic behavior to thixotropic breakdown. $t_{p}$ : appropriately selected constant.

のせん断弾性係数 $G=1200 \mathrm{~Pa}$ であった。間隙角度を $1.77^{\circ}$ とし たときも同様の結果を示した。側面から写真観察した結果は, 試 料層が一様に直線的にひずむ（例えば，Fig. 5(a)，(b) の曲線 i， ii）ことが確認された.

\section{$3 \cdot 2$ 定常流動に至るまでの全体的挙動}

ひずみが 0.1 以上になると, 弾性的挙動からずれるようになる. その一例は Fig. 3(a) の点 1 以上にみられる.点 1 亿おいて $\theta_{p}$

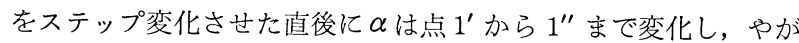
て一定值に達する。しかし，ての上うな变化は常に起こるあので なく, 点 3 まではひずみを增してあ弾性的変化とてれからのずれ とが交互に起こり，点 3 ないし 4 以後においてようやく完全な流 動に至るようにみえる。この結果とモードＩ，IIによる他の測定 例をまとめて Fig. 4 亿示す. 口印の測定点に付した点 $1 \sim 4$ が Fig. 3 の点 $1 \sim 4$ 亿対応している. Fig. 3 で点 $1^{\prime} \rightarrow 1^{\prime \prime}$ 亿応力変 化したので, Fig. 4 の 1" はやや右にずれているが, 点 3 までは 弾性係数 $G=1200 \mathrm{~Pa}$ を示す直線から大きくははずれていない. このように弾性域を越えても応力がな打上昇する傾向はFig. 4 に示したいずれの測定結果にあみられる。モードIで回転停止期 間を短縮するほど，またモードIでは平板の回転角加速度を大に するほど見掛け上弾性からのずれは少なく, かつ応力のピーク值 あ大きくなっている. 応力のピーク点以後は応力の時間変化とし て(b)図に示す．ただし，横軸の $t_{p}$ は適当に選んだ時間である。 チキソトロピー流動堂経て定常に至っていることがわかるが，(a) 図と対比して応力のピーク值が大なる程チキソトロピー的な応力 変化は急激であること, いずれの測定結果む定常状態では一定応 力に収束することなど多様な变化を示した．

これらの変化の理由を推察するために側面観察と対比した。そ の一例を Fig. 5(a)，(b) に示す. 両図はそれぞれ Fig. 4 の実線 と点線に, 図上の記号 $1 \sim 4$ は Figs. 3, 4 のそれに, i vi は. Fig. 4 のそれにそれぞれ対応させている。また，横軸 $\theta$ は陚料側 表面の局所位置 $z$ におりる回転角で, 基準を合すため相対回転角 $\left(\theta_{p}-\theta\right)$ をとって示している. 両図共に弾性範囲（曲線 $\mathrm{i}, \mathrm{ii}$ ) 㠻 越えると, 曲線 iii，ivまたは $1^{\prime \prime}, 2,4$ の上うに試料層中央部付 近に局所的なすべり*1が認められる. Fig. 3 と対応しててのすべ

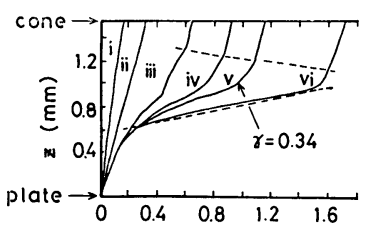

(a). $\left(\theta_{p}-\theta\right)$ (deg)

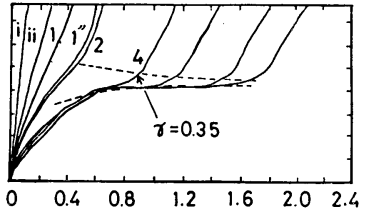

(b), $\left(\theta_{\rho}-\theta\right)$ (deg)
Fig. 5 Visualization of yielding behavior observed on lines marked on sample side surface.

(a) correspond to solid line in Fig. 4

(b) correspond to dotted line in Fig. 4

りはやがて停止する．応力を増してあすべらないととああるが， 全体としてはすべり部分は発達し，曲線 iv, v, vi のように変化 すると，同時にすべり部分の幅が点線で示すように狭まる，試料 層が全面的な流動を起こしたてとが明確に認められたのは, 曲線 vi や 4 程度に変形した後であった。乙れらはFig. 3 では応力の ピーク点にほぼ対応しており, Fig. 3ではピーク点以降でチキン トロピー変化を示している.一方可視化によると, (a) 図曲線 vi や 4 以降は $\tau$ が急速に減少するてとに対応して流動幅が急速に減 少し，中央の狭い幅内でのみが流動するに至る．他の部分は固体 化したままで剛体的に回転する。(b) 図の場合も同様であるが, $\theta_{p}$ をステップ変化させるなどして徐々にひずみを増す程すべり 部分の幅が最初から狭いことがわかった．定常流動における流動 幅は非営に狭く明確に測定出来なかった。

\section{$3 \cdot 3$ 局所すべり域における可逆的な弾性の再現}

前述のように, Fig. 3(a) で点 1 ”から 3 付近までは一旦すべ りが起ったにあかかわらず，応力を增してあすべらないととがあ った．したがって，金属と類似して微小すべりによる硬化（ひず み硬化）または弾性が再現するようにみえる。このことを検討す るために，次の二通りの実験を行った。

一つは，最大ひずみがすべりを起こすよりあやや大きくなる程 度に振幅を調整して，正弦波状のひずみ（モードIII）を加えた。 結果はFig. 6(a) 飞示しており, 履歴現象が認められる。すなわ 5, Fig. 6(b) と対比して弾性限界付近点 bに扔いてすべりが起 こり, 点 $\mathrm{c}$ まで持続する. 点 $\mathrm{c}$ 付近で $\theta_{p}$ が減少し始めると, $\gamma$ はほぼ一定のままでてのみが減少し, 点 $\mathrm{d}$ 亿至る。点 $\mathrm{d} \rightarrow \mathrm{g}$ 間は ほぼ弾性的に挙動し, 点 $\mathrm{g}$ 亿おいて再びすべりを生じ, 点 $\mathrm{i}, \mathrm{j}$ を経て点 $\mathrm{a}$ 付近で元の $\mathrm{a}-\mathrm{b}$ 植線上にほぼ復州する。なお, 履歴 曲線で点 $\mathrm{a} \rightarrow \mathrm{e}$ 間之 $\mathrm{e} \rightarrow \mathrm{a}$ 間とが対称でないのは, 平板に正確な 正弦波形を与えにくかったととによっている．とのサイクルにお ける試料層側面から観察した変形過程の一部を円錐の回転角 $\alpha$ を 基準にして Fig. 7 亿示す. 図の曲線 $\mathrm{c} \sim \mathrm{j}$ は Fig. 6(a) の点 $\mathrm{c}$ 〜 j における変形状態である. 最初のすべりは, $\mathrm{z}=0.8 \mathrm{~mm}$ 付近 で生じ（曲線 $\mathrm{c}$ ), その後点 $\mathrm{c} \sim \mathrm{d}$ 間は $\curlyvee$ ほぼ一定であるととに 対応して曲線 $\mathrm{c}, \mathrm{d}$ あほとんど変化しない. 点 $\mathrm{d} \sim \mathrm{f}$ の間はすべ った曲線形状（曲線 c) に比例する形で変形していることが注目 される. 点 $\mathrm{f}$ を経て $\mathrm{g} \rightarrow \mathrm{i}$ 特に点 $\mathrm{g}$ 付近において, 曲線 $\mathrm{g}$ の形状 が大幅に変化し二度目のすべりが起こったてとを示す. 以後曲線 $\mathrm{h}$, i のように曲線 e, c と大約対称な形状に回復してゆき, 曲

*1 局所的なずり流動とみるべきであるが，これが停止してしまい全 面的な破壊流動を起こすには至ってない範囲内をここではすべり とよぶことにする，以下同様， 


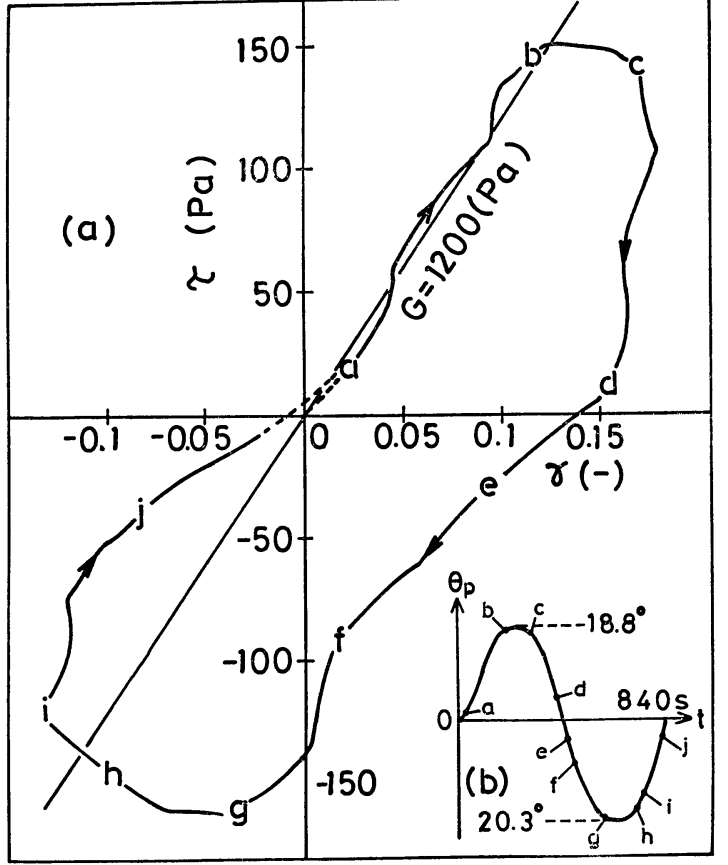

Fig. 6 An illustration of hystresis loop.

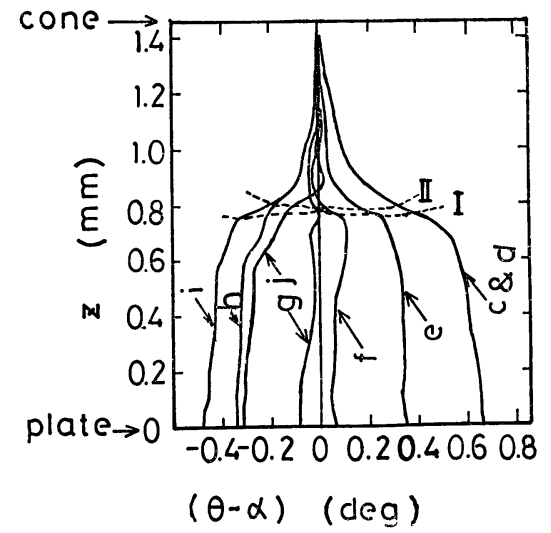

Fig. 7 Distortion visualization of sample at each points, c to j, in Fig. 6.

線 $\mathrm{j}$ は再び曲線 $\mathrm{i}$ に比例している．1サイクルから10サイクルま ではほとんど類似の挙動を示すことを確かめた。

Fig. 7 の 2 本の点線は， $z=0.8 \mathrm{~mm}$ 付近におけるマーク線上の 注目点の軌跡を画いたあのである，点線間にある曲線の幅が曲線 $\mathrm{g}$ 付近で急に減少しており，最初にすべった部分が曲線 $\mathrm{g}$ 付近に おいて二度目のすべり（現象的には二点Ｉ，II間が折れ重なる） をあたらすととが明らかになった．てのように同一部分がくり返 し反対方向にすべりを起こしながらあ, 数サイクル程度正弦波状 のひずみを加えた程度では, すべり部分が完全破断に至ることは ない.

第二の実験は，Fig. 8 亿付記したようにモードIIて局所すべり を起こすまでひずみを与え，その後応力が零になるまでひずみ灷 減じ, さらに再び連続ひずみを加えた。結果はFig. 8 亿示す. $\gamma=0.09$ 程度の残留ひずみがみられるが, 注目すべきことは再度 ひずみを加えたときの勾配が最初のそれよりあやや大きく, かつ 第二のすべりが起こるときの応力は, 再現性は悪いが最初のそれ

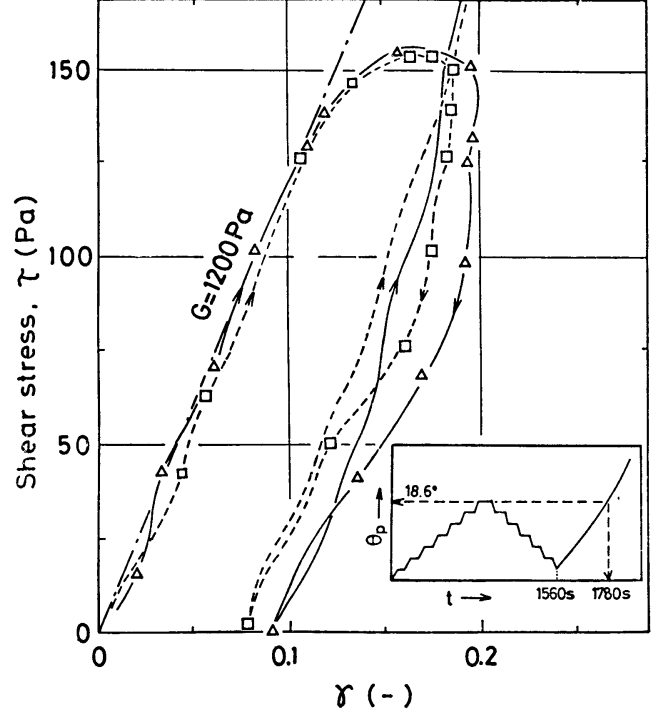

Fig. 8 An illustration of elastic recovery.

よりあ常にやや大きいことである. 図上の点線は, 第二のすべり を起こすまでの再現性をみたものである。また，乙れらの結果す 可視化とよく対応していた (図省略). 以上 Figs. 3〜 8 の実験に よってベントナイト分散系は, 緩やかにせん断を与えると低ひず み域で弾性を示すこと, 弾性範囲を越えても弾性的性質からは大 きくはずれず, 応力の增加があるととがわかった。その程度はせ ん断の負荷速度によって変わり，せ九断を比較的急速に与えた場 合は, 試料層内で広い幅にわたって変形からすべりが起こる.た めに応力の增加は著しい，せん断を極めて緩やかに与えるか段階 状に与えると, 試料首内における変形およびすべりの幅は狭くな るが，すべりを生じた部分はごく短時間の間に再び弾性を示し， 時にはひずみ硬化に類似な現象がみられるために応力の增加を示 す.いずれにしてあ全面的に流動するようになると流動の幅は急 速に狭まり，てれに伴なってせん断力屯急減する。試料層内部の 状態が側表面の可視化結果に代表されているとすると, ベントナ イトスラリーの破壊に関して次のような仮説が考えられる.

すべりは微視的に結合の弱い部分から起こるであろうが，その 際金属材料のように弱い部分が孤立して微小龟裂を生じすべると いうょりあ, むしろ各所に存在する弱い部分が相互に連携し合っ た形で相対的に広い範囲にすべり始める．ために負荷されるひず み速度が大きいほど応力が広く伝播され, 幅広くすべりが起こる (Fig. 5).

一方, 渡辺 $弓^{9)}$, Weymann $ら^{10)}$ とよる, ベントナイトの降 伏値は非常に速く可逆回復する要素と長時間にわたってゆっくり 硬化する要素よりなる.両者の降伏值之時定数をそれぞれ $\tau_{y 1}, \tau_{y 2}$ 抢よび $\lambda_{1}, \lambda_{2}$ とすると，乙れらと応力負荷速度との競合関係に よって様々な現象が出現する．Fig. 3を例による．応力增加が緩 慢加弾性限界を大きくは越えない場合 (Fig. 3 点 $1^{\prime}$ ) には, 最 屯弱い部分を中心にして部分的にすべりが起こるが，すべりに伴 う応力低下の間に $\lambda_{1}$ がきき $\tau_{y 1}$ 程度の応力回復 (前項では弾性 の再現によるとみなした）が可能となる.ために，すべりは減速 され遂に停止するに至る (Fig. 6 点 $\mathrm{d}-\mathrm{g}$ なども同様). 弾性の再 現は一様でなく，すべり部分のうちであ早く回復したすの程 $\tau_{y 2}$ 


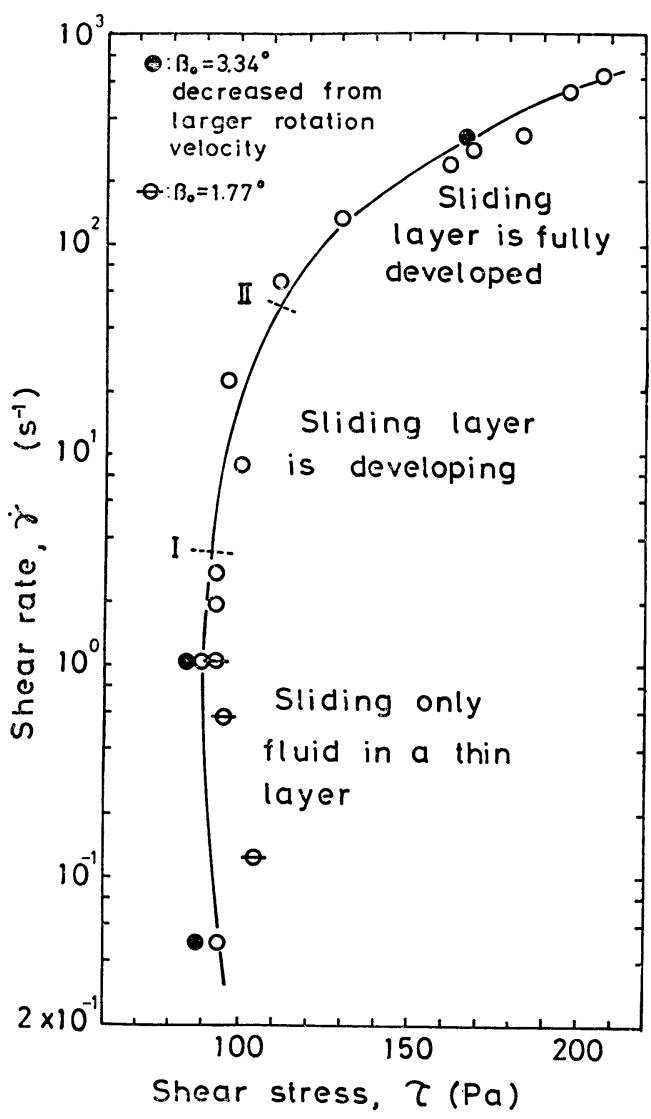

Fig. 9 Flow behavior at steady state.

が重なり，より強固になるであろう。そこで負荷応力を引続き漸 增させるとより, 崌く回復した部分のみが二度目のすべりを起こ す. かくしてすべり幅は漸次狭まり完全破断に至る (Fig. 5)*1.

Fig. 7 にみられるひずみ硬化に類似な現象は，レオペクシーあ るいは shear-thickening とみられなくあないが，本試料は本質的 には shear-thinning なあのであって, shear-thickening 類似の性 質は応力回復が可能かつ負荷応力が，弾性限界よりあやや大であ るなどの限られた条件下でのみ出現するとみなすのが妥当であろ うと考えられる。

\section{$3 \cdot 4$ 定常流動挙動}

極低速回転では定常状態の試料層はごく一部のみが流動し，他 は固化したままであった．定常回転速度を十分大にし試料層全体 在流動化した後，最初の設定值まで下げても定常状態に達したと

*1 応力負荷が急速かつ十分大であるときは応力回復は期待出来ず， 単に急激な応力伝播に伴う過大な応力增加と共に層全体がすべり 流動を起こす。
きは同様の状態を再現した。乙れは前項に記したように結合の可 逆回復に起因するすのとすると，測定方法によらず一般にみられ るはずである. 既往の測定結果は定常の $\tau-\dot{\gamma}$ 特性が多いので, 対 比のためにてれを測定した。結果は Fig. 9 亿示す. 図中には一 旦高速回転 (364.7 r.p.m. で30分間) を与えてから所定の回転数 に下げた場合 (の印)，円錐平板間隙角 $1.77^{\circ}$ の場合（○印）す

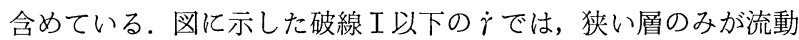
する領域，Iを越えると流動幅が漸次拡がり II 亿至って層全体が 完全に流動するようになる．破線 IIを境に流動特性は明らかに相 違している．II以下の $\dot{\gamma} は$ 真のそれでないことに一因はあるが,

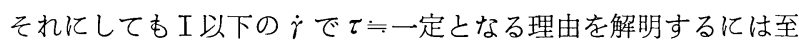
っていない.

\section{4. 結 論}

ベントナイトは本実験範囲内ではひずみの付加方法に関係なく, ひずみが 0.1 以下でほぼ弾性体とみなしえた。ひずみが 0.1 以上 において局所的なすべりを生ずる．初期すべりの範囲とその後の すべり幅の変化はひずみの付加速度に依存する，付加速度が大き いほど初期すべりの幅招よびてれの時間に伴う減小率は大で，大 きな応力増加が測定される.すべった後の応力回復はかなり急速 で，ヒステリシスや場合によってはひずみ硬化が表れる．定常流 動特性の測定結果が多様化する一因は，ひずみ速度が小さいとき， 試料層全体が流動しなくなるためである。

（1981年10月28日，第29回レオロジー討論会にて発表）

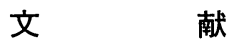

1) Cheng, D.C.-H., Rheol. Acta, 12, 228 (1973).

2) Rehbinder, P., in "Proc. 5th Int. Congr. Rheol.", S. Onogi (Ed.), Vol. 2, p. 375 (1970) Tokyo Univ. Press, Tokyo.

3）清水清, 後藤康平, 材料, 16(166), 453 (1967).

4）梅屋薫, 日本レオロジー学会誌, 4, 91 (1976).

5）松本孝芳, 人見千代次, 小野木重治, 材料, 22,421(1973).

6）岡田賢治, 長瀬洋一, 日本レオロジー学会投稿中.

7) 岡田賢治, 長瀬洋一, 佐賀義弘, 粉体工学会誌, 18(1), 23 (1981).

8）日本粘土学会編，“粘土ハンドブック”，p. 56 (1967) 技 報堂.

9) Watanabe, T., and Y. Takasaki, Naturwissenschaften, 45(14), 334 (1958).

10) Mercer, H.A., and H.D. Weymann, Rheol. Acta, 13, 413 (1974). 